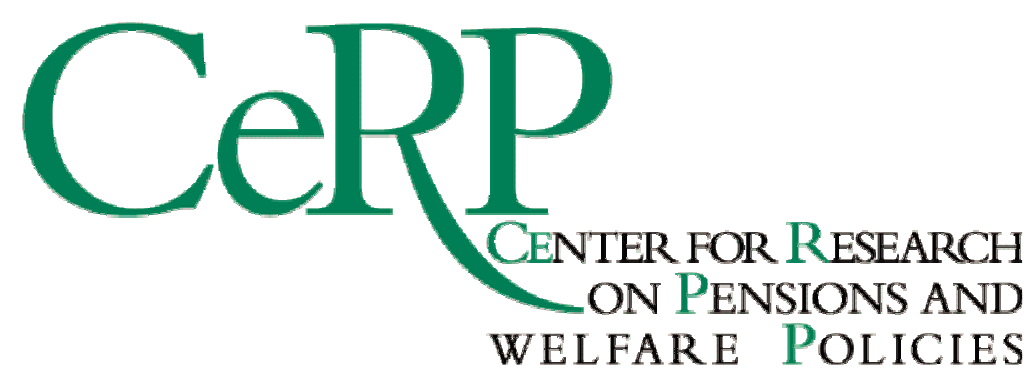

Working Paper 86/09

\title{
MICROSIMULATION OF PENSION REFORMS: BEHAVIOURAL VERSUS NONBEHAVIOURAL APPROACH
}

\author{
Margherita Borella
}

Flavia Coda Moscarola

April 2009 


\title{
MICROSIMULATION OF PENSION REFORMS: BEHAVIOURAL VERSUS NONBEHAVIOURAL APPROACH
}

\author{
Margherita Borella \\ Flavia Coda Moscarola
}

February 2009

\begin{abstract}
We analyse the impact of various pension regimes, as shaped by recent Italian reforms, on retirement age, adequacy issues, and redistribution. We add to the literature on microsimulation by accounting for individuals' reactions to financial incentives when deciding to retire. We find that shifting from a generous defined benefit (DB) system to an actuarially fair notional defined contribution (NDC) system induces individuals, particularly men, to postpone retirement. Voluntary postponement of retirement and, above all, participation in the second pillar would grant a comprehensive replacement rate (first plus second pillars) comparable to that obtained with the first pillar alone in the pre-reform DB regime.
\end{abstract}

JEL: C63, H55, J26

Keywords: Microsimulation, public pensions, retirement.

We would like to thank Chiara Monticone for her help in updating CeRPSIM to legislative evolution and Elsa Fornero, participants to the $4^{\text {th }}$ Euroframe Conference (Bologna, Italy), and participants to the CEPS conference on Microsimulation Models (Brussels, Belgium) for useful comments. We gratefully acknowledge financial support from MIUR (PRIN 2006) and Fondazione CRT (Progetto Alfieri 2006).

\footnotetext{
- University of Turin and CeRP - Collegio Carlo Alberto. E-mail address: borella@econ.unito.it.

$\checkmark$ CeRP - Collegio Carlo Alberto. E-mail address: coda@,cerp.unito.it.
} 


\section{Introduction}

Public pension systems raise sustainability and adequacy concerns that often seem at odds. In particular, many reforms undertaken for recovering financial sustainability reduce the generosity of pension benefits. In the EU15 countries, the fraction of elderly at risk of poverty displays a generally increasing trend among countries in which the social security system is under reform. In Italy, for example, the poverty rate increased from 18 percent in 1996 to 22 percent in 2007 (Eurostat, 2009).

Italy has experimented with various solutions to reform its unsustainable defined benefit (DB) public pension system. The first reform in 1992 set up a modified DB system in which pension benefits were linked to lifetime average earnings and eligibility requirements were tightened. The second major reform in 1995 designed a notional defined contribution (NDC) system whose main principles were a pension benefit based on contributions paid and on life expectancy, with very flexible eligibility requirements. The third major reform in 2008 considerably tightened the age requirements to claim a pension.

The Italian social security reform process constitutes a sort of natural experiment for analysing the consequences of various pension regimes. Our paper studies the different incentives to retirement implicit in the various pension systems, as well as their redistributive and adequacy properties. Two different branches of the economic literature analyse this topic. The first one focuses on the analysis of the economic determinants of retirement behaviour, while the second focuses on the simulation of the effects of pension reforms (on distribution, sustainability, etc.). Usually the second line of research builds microsimulation models endowed with very simple (and nonbehavioural) rules for retirement, for example, assuming that individuals retire as soon as eligible (Borella and Coda Moscarola, 2006) or aligning the exits to the observed patterns (Mazzaferro and Morciano, 2005; Dekkers et al., 2009; Richiardi and Leombruni, 2006). Social security rules are, however, expected to influence the optimal working and retirement paths by both constraining retirement decisions into a specific range of possible retirement ages and generating financial incentives to retire at later ages. 
The retirement behaviour literature accounts for the role played by financial incentives embedded in the pension rule, reconciling the empirical evidence with lifecycle theory. Coile and Gruber (2000) for the United States, Baker et al. (2003) for Canada, Blundell et al. (2002) for the United Kingdom, and Alessie and Belloni (2009) for Italy, just to name a few, all find that individuals' retirement choices do respond to financial incentives embedded in the public pension system as well as to social security wealth. In particular, the absence of age-related (dis)incentives in defined contribution plans has been found to lead U.S. workers to retire almost two years later compared with workers under DB plans (Friedberg and Webb, 2005).

Our study simulates the effects of the major social security reforms undertaken in Italy during the last 20 years, adding to the literature on microsimulation by accounting for individuals' reactions to financial incentives when deciding to retire. For this purpose we use a cohort microsimulation model in which retirement behaviour is treated in a probabilistic way using the retirement decision rule estimated by Alessie and Belloni (2009) for Italian workers. The inclusion of a behavioural rule depending on financial incentives allows one to capture different retirement behaviour under alternative pension systems, as well as investigate these systems' adequacy and distributive properties.

This paper is organised as follows. Section 2 reviews the main features of the pension reforms that occurred between 1992 and 2009, focussing on the main three reforms that deeply changed the financial incentives to prospective retirees. Section 3 describes our microsimulation model and specifies the main hypothesis underlying our simulation exercise. Section 4 shows the simulated effects of the various pension regimes on the average age of retirement, adequacy issues, and redistribution. Section 5 presents our conclusions.

\section{The Italian Pension System}

In the last two decades the Italian pension system has undergone a number of major reforms, all directed to recover long-term sustainability. Indeed, the pre-reform (pre-1992 in what follows) system was characterised by a DB pension formula based on the last few years of earnings combined with soft eligibility rules, without any actuarial correction for age at retirement (see Table 1). 
The first reform, which took place in 1992, set new — and more stringent eligibility requirements while preserving the DB system. After the transition phase, pensionable earnings were based on the entire worker's earnings history and revaluated at the nominal GDP growth rate. No actuarial correction for age at retirement was provided for, but the pension indexation mechanism was downgraded from wages to prices. Such an indexation mechanism has been since maintained by all subsequent reforms.

The reform approved in 1995 rescheduled a new (and long) transition towards an NDC formula. The NDC formula harks back to actuarial fairness principles. Benefits are commensurate with the amount of payroll taxes paid capitalised at an interest rate equal to GDP's rate of growth of the and annuitised according to life expectancy at retirement. Accessibility to retirement was made more flexible. Individuals were entitled to retire from the age of 57 onwards, subject only to the constraint of having a pension higher than 1.2 times the minimum old age allowance ${ }^{1}$. Subsequently, adequacy concerns drove the introduction of incentives for private sector employees and self-employed workers to start contributing to private pension plans (Budget Law, December 2006).

Finally, the 2008 reform stepped in to modify the NDC regime. From 2008 onwards, the age requirement to claim a seniority pension has been gradually raised. For younger cohorts of workers completely under the NDC regime - such as the ones we consider in our study — the minimum retirement age was raised to 60 for women and to 65 for men. At the same time, the possibility of claiming a seniority benefit has been reintroduced by imposing a complex system of requirements of age plus seniority (see Table 1).

\footnotetext{
1 Two additional minor reforms changed the eligibility rules set by the 1995 reform. The 1997 and 2004 reforms sought to shorten the transition period while preserving the NDC system and tightened the eligibility requirements for seniority DB pensions. Meanwhile, a means-tested supplementary old-age allowance was introduced in 2002 directed to the elderly poor.
} 
Table 1. Main characteristics of the pension reforms in Italy.

\begin{tabular}{|c|c|c|c|c|c|c|}
\hline \multirow[b]{2}{*}{ Reform } & \multicolumn{3}{|c|}{ Private employees } & \multicolumn{3}{|c|}{ Self-employed } \\
\hline & Pension formula & Seniority pension & Old-age pension & Pension formula & Seniority pension & Old-age pension \\
\hline Pre-1992 & $\begin{array}{l}\text { DB: average of last } 5 \\
\text { years earnings } \times 0.02 \times \\
\text { years of seniority }\end{array}$ & $\begin{array}{l}\text { Men and women: } \\
\text { min } 35 \text { years; } \max \\
40 \text { years; no age } \\
\text { requirements }\end{array}$ & $\begin{array}{l}\text { Men: age } 60+, \\
\text { seniority } 15 \text { years } \\
\text { Women: age } 55+, \\
\text { seniority } 15 \text { years }\end{array}$ & $\begin{array}{l}\text { DB: average of last } 10 \\
\text { years income } \times 0.02 \times \\
\text { years of seniority } \\
(\text { since the } 1990 \text { reform })\end{array}$ & $\begin{array}{l}\text { Same as private } \\
\text { employees }\end{array}$ & $\begin{array}{l}\text { Men: age } 65+\text {, } \\
\text { seniority } 15 \text { years } \\
\text { Women: age } 60+\text {, } \\
\text { seniority } 15 \text { years }\end{array}$ \\
\hline 1992 & $\begin{array}{l}\text { DB: average of } \\
\text { indexed lifetime } \\
\text { earnings } \times 0.02 \times \text { years } \\
\text { of seniority }\end{array}$ & Same as pre-1992 & $\begin{array}{l}\text { Men: age } 65+, \\
\text { seniority } 20 \text { years } \\
\text { Women: age } 60+, \\
\text { seniority } 20 \text { years }\end{array}$ & $\begin{array}{l}\text { DB: same as private } \\
\text { employees }\end{array}$ & $\begin{array}{l}\text { Same as private } \\
\text { employees }\end{array}$ & $\begin{array}{l}\text { Same as private } \\
\text { employees }\end{array}$ \\
\hline 1995 & $\begin{array}{l}\text { NDC: lifetime payroll } \\
\text { taxes capitalised at the } \\
\text { GDP rate of growth; } \\
\text { converted into annuity } \\
\text { with actuarially fair } \\
\text { coefficients }\end{array}$ & \multicolumn{2}{|c|}{$\begin{array}{l}\text { Men and women: possibility of } \\
\text { retirement between ages } 57 \text { and } 65 \text {, with } \\
\text { a min of } 5 \text { years of seniority; accrued } \\
\text { pension }>1.2 \text { times the minimum old } \\
\text { age allowance to claim pension before } \\
65\end{array}$} & $\begin{array}{l}\text { NDC: same as private } \\
\text { employees }\end{array}$ & \multicolumn{2}{|c|}{ Same as private employees } \\
\hline 2008 & NDC: same as 1995 & $\begin{array}{l}\text { Men and women: } \\
\text { min age } 61+\text { min } \\
\text { seniority } 35 \text { years } \\
+ \text { sum(age; } \\
\text { seniority })>=97\end{array}$ & Same as 1992 & $\underline{\text { NDC: }}$ same as 1995 & $\begin{array}{l}\text { Men and Women: } \\
\text { min age } 62+, \text { min } \\
\text { seniority } 35 \text { years } \\
+ \text { sum(age; } \\
\text { seniority) }>=98\end{array}$ & $\begin{array}{l}\text { Same as private } \\
\text { employees }\end{array}$ \\
\hline
\end{tabular}




\section{The Microsimulation Model}

Our analysis is conducted using CeRPSIM2, an updated and expanded version of CeRPSIM (Borella and Coda Moscarola, 2006). According to the taxonomy proposed by Bourguignon and Spadaro (2006), CeRPSIM2 is a dynamic partial-equilibrium microsimulation model of the social security system which relies on a behavioural rule for modelling retirement decisions ${ }^{2}$. It is designed to analyse the distributional features embedded in the Italian pension system during its transition from a DB to an NDC system. It is composed of three main modules: the population module, the pension module, and the retirement module ${ }^{3}$.

The population module is designed to support a cohort population and is able to simulate lifetime patterns for individuals born since 1950. In this study, however, we focus on a single cohort born between 1991 and 2000 (with median year of birth 1995) and analyse its behaviour through subsequent reforms of the pension system. The advantage of this methodology is that different pension rules are applied to the same group of individuals, with the same working history, so that the outcomes vary only in response to the pension reforms. The simulated population evolves in accordance with a set of deterministic and stochastic elements conditional on individual socioeconomic characteristics. Particular attention has been devoted to modelling individuals' earnings paths as the sum of a group-specific deterministic component and an individual-specific stochastic component estimated from a panel of administrative data.

The pension module computes pension benefits according to the various pension regimes set up by Italian legislation up to 2008. This is a very detailed module able to compute pensionable earnings and contributions paid, check eligibility requirements, and compute the pension benefits for a number of schemes and different regimes. Pension benefits are computed for individuals who retire from the year 2000 onwards. The program is able to replicate the pre-1992-reform rules as well as each of the subsequent reforms, up to 2008 .

\footnotetext{
${ }^{2}$ For a survey on microsimulation models see also Creedy and Kalb (2006),

${ }^{3}$ A detailed description of the microsimulation model is provided in Appendix.
} 
The retirement module determines whether an eligible individual actually retires according to two alternative criteria. First, individuals are assumed to claim their pension benefit as soon as they are eligible: This requires not only that they meet the minimum age and seniority eligibility requirement but also that they wait for an 'exit window' to become active ${ }^{4}$. This nonbehavioural criterion depicts the 'minimum age' scenario that we use as baseline.

Second, we model retirement behaviour in a probabilistic way using the retirement decision rule estimated by Alessie and Belloni (2009) on a sample of Italian workers during the period 1985-2000. Their probit estimates highlight the key role played by the economic incentives to retirement implicit in the pension scheme, in line with previous research for the United States (Gruber and Wise, 2004; Coile and Gruber, 2000; Baker et al., 2003). Including this retirement behavioural equation in our microsimulation model allows us to define an 'optimal age' scenario to be compared with the 'minimum age' one.

\subsection{Cohort definition and parameters}

We simulate one cohort of individuals, born between 1991 and 2000 (hereafter cohort 1995, from the median year of birth). We calculate the main life events relevant for the retirement of about 12,000 heterogeneous individuals, about 6,000 of which are employed in the private sector or self-employed. We restrict our attention to these two categories of workers, as public sector employees and other minor schemes are not covered by our retirement behavioural equation. We then study the retirement outcome of this cohort under different retirement rules, as defined in our retirement module, and under different pension legislation.

To study the impact of the reforms on retirement behaviour, we show the results as if the pre-1992 system were still in place and then implement the main subsequent reforms one at a time. Therefore our results show, for the same population, the effects of

\footnotetext{
${ }^{4}$ Since 1992, workers eligible to claim a pension can retire only in predetermined periods during the year, the so-called exit windows. With this mechanism, retirement is delayed by 6 to 18 months, depending on seniority, scheme, and pension reform.
} 
the DB system (pre-1992 system), the less generous modified DB system (the 1992 reform), the actuarially fair NDC system (the 1995 reform), and the NDC system with tighter minimum age requirements (the 2008 reform).

When we simulate the 2008 reform, we assume that all workers participate in the second pillar. Workers belonging to the private sector are assumed to automatically transfer their entire severance pay flows (6.91 percent of their gross wages) to pension funds from 2007 on; self-employed workers are also hypothesised to participate in the second pillar with a contribution rate equal to that of private employees.

Throughout all the calculations presented in this paper we use a discount rate equal to 1.5 percent in real terms. As will be seen, this assumption helps in the evaluation of the long-term convenience of participating in the social security system. The rate of return of the pension fund is fixed at 2 percent in real terms, net of administrative costs. The real GDP growth rate and future inflation rate are set equal to 1.5 and 1.6 percent, respectively.

All the simulations are based on RG48 cohort mortality tables (see Appendix for a description) that are kept invariant over the projection horizon. The annuity rates for the computation of the pension benefits under the NDC rule are calculated accordingly. Minimum pensions, minimum contributions, and ceilings are indexed to nominal GDP growth.

\subsection{Measures for adequacy and distribution analysis}

We wish to study the effects of the introduction of a behavioural rule on individual retirement age, on the adequacy of the pension benefits received at that age, and on the distributive impact of the pension rules.

As a measure of adequacy we use the replacement rate (RR) calculated as the ratio between the first pension benefit and the average of the last three wages received by an individual. It is a measure of the level of benefits and of the ability to preserve purchasing power during retirement. While certainly not exhaustive, the RR can be a good starting point for exploring the adequacy of the pension system. In particular, low- 
income individuals, who would not have accumulated wealth, would need nearly a 100 percent net RR to avoid a drop in consumption after retirement (see Smith, 2003).

As in Feldstein and Liebman (2002), we interpret social security as an insurance provision against longevity risk and attribute any departure from actuarial neutrality to redistribution. The intergenerational distributive impact of the pension system is investigated by using the present value ratio (PVR), while the intragenerational one is explored through the so-called RS index proposed by Reynolds and Smolensky (1977). The PVR is the benefit-to-tax ratio, that is, the ratio between the present value of the pension benefits to be received and the present value of payroll taxes paid, both valued at retirement. If greater than 1 when calculated at an interest rate equal to the GDP's growth rate, then the system is granting to retired individuals more than would be justified in a pension system in financial equilibrium. The system is redistributing resources from (future) generations active in the labour market to currently retired ones.

The RS index is defined as the difference between the Gini coefficients of lifetime income under an hypothetical actuarially fair system and under the actual system. Since an actuarially fair system perfectly preserves the original distribution of lifetime income, the RS index measures the variation in the inequality of lifetime income induced by the actual pension system. If this variation is positive, the actual pension system is benefiting the less well off relative to the better off.

\section{Results}

Our results are based on the simulation of cohort 1995, to which we apply in turn the different pension systems devised by the reforms in Italy. As previously described, these reforms allow us to compare results under rather typical pension systems: a DB system with a benefit based on the last few earnings (pre-1992), a DB system based on average lifetime earnings (1992), an NDC system with a fair degree of flexibility in retirement age (1995), and, finally, an NDC system with stricter eligibility rules (2008). 


\subsection{The effect of the reforms on retirement age}

Table 2 shows the average retirement age of our population for each reform. Results are reported for both the nonbehavioural rule, which posits that each individual retires as soon as possible, and the behavioural model, which adopts the behavioural rule described above to assess whether an individual postpones retirement or not. The nonbehavioural results are useful to assess the effects of the minimum age requirements of each pension system considered, while the effect of the changing financial incentives is observed by comparison with the behavioural results.

As reported in Table 2, the reform process unequivocally leads to a progressive rise in the average retirement age of individuals because of both the increase in the minimum age requirements to qualify for a pension (as can be seen in the nonbehavioural scenario) and the annullment of the financial incentives to early retirement (the behavioural scenario). According to the nonbehavioural results (first two columns in Table 2), the average retirement age under the pre-1992 system would have been around 57.9 years for men and around 55.4 years for women, whereas after the 2008 reform these numbers are about 62.2 years for men and about 61.4 years for women. These nonbehavioural results represent the average of the minimum retirement age of our simulated workers.

When taking into account the choice of retirement (third and fourth columns in Table 2), that is, the reaction of individuals to financial incentives and the role played by the preferences for leisure during old age, the average retirement age of workers rises further under each scenario: after the 2008 reform the average age reaches 62.8 years for men starting from 59 years under the pre-1992 system — and 61.5 years for women — instead of 56.2 years under the pre-1992 scenario. 
Table 2. Average age of retirement by reform, gender, and retirement rule.

\begin{tabular}{|c|c|c|c|c|c|}
\hline \multirow[b]{2}{*}{ Reform } & \multirow[b]{3}{*}{ Age } & \multicolumn{2}{|c|}{ Nonbehavioural } & \multicolumn{2}{|c|}{ Behavioural } \\
\hline & & Men & Women & Men & Women \\
\hline \multirow[t]{2}{*}{ Pre-1992 } & & 57.9 & 55.4 & 59.0 & 56.2 \\
\hline & Freq. & 3612 & 2216 & 3580 & 2214 \\
\hline \multirow[t]{2}{*}{1992} & Age & 59.0 & 57.6 & 60.1 & 57.9 \\
\hline & Freq. & 3588 & 2208 & 3552 & 2207 \\
\hline \multirow[t]{2}{*}{1995} & Age & 58.4 & 59.9 & 60.2 & 60.3 \\
\hline & Freq. & 3599 & 2196 & 3540 & 2194 \\
\hline \multirow[t]{2}{*}{2008} & Age & 62.2 & 61.4 & 62.8 & 61.5 \\
\hline & Freq. & 3486 & 2186 & 3448 & 2185 \\
\hline
\end{tabular}

Beyond the expected conclusions about the increase in the average retirement age, further disentangling the results by working scheme reveals many interesting aspects that account for the great heterogeneity in the career profiles and pension rules of the selfemployed and of employees. In particular, it is a common perception that under the pre1992 DB rule, the financial incentives to early retirement were so high that the retirement age coincided mostly with the age of eligibility. Our simulation results only partially support such a thesis. Under the pre-1992 scenario the difference between the average optimal (behavioural) and minimum (nonbehavioural) retirement ages is about 0.8 year for male and female private employees and 0.7 year for self-employed women, while it reaches 2.5 years for self-employed men $^{5}$. The minimum retirement age for the selfemployed does not substantially differ by gender and is about 57.4 years, while the optimal retirement age is 58.1 years for women and 59.9 years for men. Among private employees men display a minimum retirement age of about 58 years and an optimal one of 58.8 years, while women have the lowest retirement ages, the minimum age being 55.1 years and the optimal one being 55.9 years.

5 These numbers are obtained by subtracting the minimum (nonbehavioural) age from the optimal (behavioural) retirement age under the pre-1992 scenario reported in Table 3. 
Table 3. Average age of retirement by reform, gender, working scheme, and retirement rule.

\begin{tabular}{|c|c|c|c|c|c|c|c|c|c|}
\hline \multirow{3}{*}{ Reform } & & \multicolumn{4}{|c|}{ Nonbehavioural } & \multicolumn{4}{|c|}{ Behavioural } \\
\hline & & \multicolumn{2}{|c|}{ Men } & \multicolumn{2}{|c|}{ Women } & \multicolumn{2}{|c|}{ Men } & \multicolumn{2}{|c|}{ Women } \\
\hline & & Private & Self & Private & Self & Private & Self & Private & Self \\
\hline \multirow[t]{2}{*}{ Pre-1992 } & Age & 58.0 & 57.4 & 55.1 & 57.4 & 58.8 & 59.9 & 55.9 & 58.1 \\
\hline & Freq. & 2983 & 629 & 1888 & 328 & 2967 & 613 & 1886 & 328 \\
\hline \multirow[t]{2}{*}{1992} & Age & 59.3 & 57.4 & 57.7 & 57.4 & 60.5 & 58.0 & 58.0 & 57.6 \\
\hline & Freq. & 2959 & 629 & 1880 & 328 & 2931 & 621 & 1879 & 328 \\
\hline \multirow[t]{2}{*}{1995} & Age & 57.7 & 61.6 & 59.5 & 62.0 & 59.7 & 62.7 & 59.9 & 62.2 \\
\hline & Freq. & 2999 & 600 & 1868 & 328 & 2954 & 586 & 1866 & 328 \\
\hline \multirow[t]{2}{*}{2008} & Age & 62.2 & 62.5 & 61.2 & 62.4 & 62.8 & 63.0 & 61.4 & 62.4 \\
\hline & Freq. & 2888 & 598 & 1858 & 328 & 2864 & 584 & 1857 & 328 \\
\hline
\end{tabular}

The motivation for this evidence is easily found in the life-cycle theory framework. Retirement decisions, in fact, depend on many factors, primarily individual preferences for nonworking time (leisure and time devoted to household production), marginal financial incentives to retire early, and expectations about future consumption needs. While the first two factors encourage the individual to anticipate retirement, the third one discourages it. The final outcome is a composite of these effects and, according to the results presented, the third factor appears to more than compensate for the first two.

By tightening the eligibility requirements for employees, the 1992 reform raises their minimum retirement age while, by confirming the previous requirements for the self-employed, leaving their nonbehavioural retirement age unchanged ${ }^{6}$. Nevertheless, it also changed the financial incentives to retirement, the direction and magnitude of such a change depending on the shape of the earnings profile for each category of workers considered. In particular, male employees seem to react by postponing their retirement on average by 1.2 years — that is, 0.4 year more than in the pre-1992 system — reaching an

\footnotetext{
${ }^{6}$ Recall that the 1992 reform will never be applied, as it has been replaced by the 1995 reform.
} 
average behavioural retirement age of 60.5 years. On the other hand, female employees and the self-employed (both men and women) postpone their retirement age on average by at most 0.6 year, so that the incentive to postpone for them is less than under the previous system (especially in the case of self-employed males).

The 1995 reform, together with a less generous pension benefit computed according to an NDC system, introduced flexibility in the retirement age after the age of 57. Workers with pension benefits below a certain threshold (1.2 times the income support for the elderly), however, cannot retire before turning 65. This rule explains the average nonbehavioural retirement age displayed in Table 3: while for male employees it is lower with respect to the previous DB systems (57.7 instead of 59.3 years under the 1992 reform), for all other categories the reverse is true, meaning that is more likely for male employees to accrue a low pension benefit and be forced to postpone retirement ${ }^{7}$. In particular, the minimum average retirement age reaches 59.5 years for female employees, while that for self-employed men and women is 61.6 and 62.0 years, respectively.

As for the behavioural response, the relative strength (and eventually the direction) of the forces driving retirement decisions are expected to change deeply under the NDC system, which removes the financial disincentives to work typical of a DB system. In particular, it is a common perception that under the more strictly defined contribution rule of the 1995 reform individuals will tend to postpone retirement well beyond the minimum retirement age (even more than before), despite the lower minimum age requirement to access pensions. Our simulations confirm such a thesis for men but find scant evidence for women. The average optimal age for men is in fact 2 years higher than the minimum for private employees and 1 year higher for the self-employed, while for women the gap reduces to less than half a year ( 0.5 year for employees, 0.2 year for the self-employed $)^{8}$.

Finally, Table 3 further allows us to understand if the constraints on the minimum retirement ages imposed by the 2008 reform will result to be binding. To answer the

\footnotetext{
${ }^{7}$ Payroll tax rates are much lower for the self-employed, hence pension benefits accrued are likely lower than the minimum threshold to access retirement.

8 These results follow both from the different incentives faced by the different groups (e.g., because of the different earning profiles) and from the coefficients of the behavioural rule, which highlight a greater response by men (with respect to women) as far as marginal financial incentives are concerned.
} 
question we have to compare the behavioural average age under the 1995 reform with the non-behavioural average age under the rules of the 2008 one $^{9}$. According to our results, the 2008 reform is expected to be binding for private employees, whose optimal retirement age under the 1995 system is lower than the minimum retirement age required after the 2008 reform. The average optimal retirement age expected under the 1995 regime is in fact 59.7 years for male employees and 59.9 years for female employees. The minimum retirement age under the 2008 regime is higher and equal to 62.2 years for men and 61.2 years for women.

In contrast, the 2008 reform does not seem to be binding for the self-employed, especially men. The lower contribution rates of the self-employed coupled with the NDC system (both the 1995 and 2008 systems) will lead these workers to accrue lower pension benefits and adequacy concerns will push them to work longer. Indeed, the average optimal retirement age expected under the 1995 regime is 62.7 years for males and 62.2 years for females, while the minimum age under the current regime is 62.5 years for men and 62.4 years for women.

\subsection{Adequacy}

The debate on the effects of the NDC reforms is focussed on the question of the adequacy of the pension benefits even more than on the average retirement age. The common perception is that the Italian DB system is adequate from the point of view of the level of the benefits provided, while the NDC system is not. In order to assess the adequacy of the different pension systems, Table 4 shows the median and mean RRs granted to our simulated workers under the different reforms, computed as the ratio of the first pension benefit to the average of the last three years of earnings ${ }^{10}$. We assume that earnings and pension benefits are a good approximation of living standards before and after retirement. While consumption would probably be a better proxy, it is not computed

\footnotetext{
9 Such a comparison cannot be extended to the evaluation of the impact of each one the previous reforms, simply because those reforms not only changed the minimum age requirement, as did the 2008 reform, with respect to the 1995 one, but also changed the rule for computing pension benefits and, with them, the financial incentives to retirement.

${ }_{10}$ All figures are gross and do not take into account income taxes or the payroll tax in the worker's charge unless otherwise stated.
} 
in our microsimulation model; for a detailed discussion of RR criticalities, see Borella and Fornero (2009).

As shown in the nonbehavioural scenario in the left panel of Table 4, the pre-1992 system would grant our simulated workers an RR in the range of 63-70 percent, while in the behavioural scenario, since the retirement age is higher, the RR would be greater and would range from 65 to 73 percent. After the 1992 reform, the median nonbehavioural (minimum) and behavioural (optimal) RRs tend to increase. This happens not only because the minimum retirement age tends to increase but also because in the 1992 formula the revaluation coefficients of the lifetime earnings are higher than the ones adopted in the previous system. Despite the longer reference period for the computation of the pensionable earnings characterising the modified DB formula, flat-earnings careers benefit more from the revaluation coefficients. As a consequence, female employees face the highest increase in RR.

With the 1995 reform, that is, with the NDC system, the RR granted for each year of contribution is lower, especially at younger ages. The median minimum RR for private employees under the 1995 system ranges between 48 and 54 percent for men and women, respectively, depending on the retirement scenario. Self-employed workers show a greater reduction in their RRs, which fall to $37-41$ percent. This reduction is due to their lower payroll tax rate -20 versus 33 percent for employees - which was unaccounted for by the DB system, although it plays an important role in the NDC system.

By increasing the minimum retirement age, the 2008 reform raises the $R R$ for all the categories considered. The median behavioural RR for private employees reaches a value equal to 66 percent for men and almost 60 percent for women. The change in the degree of adequacy of pensions for private employees appears to be only partially threatened by the less generously defined contribution rule: The median RR for men is almost equal to that attained in the pre-reform system, while the one for women is about 5 percentage points (pp) lower. As for the self-employed, the adoption of an NDC rule, coupled with their lower contribution rate, results in median RRs close to 40 percent, that is, about 20$30 \mathrm{pp}$ lower than in the pre-1992 regime. 
Table 4. RR by reform, scheme, gender, and retirement rule.

\begin{tabular}{|c|c|c|c|c|c|c|c|c|c|}
\hline & & \multicolumn{4}{|c|}{ Nonbehavioural } & \multicolumn{4}{|c|}{ Behavioural } \\
\hline & & \multicolumn{2}{|c|}{ Men } & \multicolumn{2}{|c|}{ Women } & \multicolumn{2}{|c|}{ Men } & \multicolumn{2}{|c|}{ Women } \\
\hline & & Private & Self & Private & Self & Private & Self & Private & Self \\
\hline \multirow[t]{3}{*}{ Pre-1992 } & Median & 66.38 & 69.85 & 63.25 & 67.19 & 67.25 & 72.67 & 64.59 & 67.55 \\
\hline & Mean & 66.93 & 69.4 & 66.97 & 67.7 & 67.78 & 72.82 & 68.54 & 68.22 \\
\hline & Freq & 2983 & 629 & 1888 & 328 & 2967 & 613 & 1886 & 328 \\
\hline \multirow[t]{3}{*}{1992} & Median & 68.86 & 72.98 & 69.05 & 69.95 & 70.24 & 73.48 & 69.21 & 69.77 \\
\hline & Mean & 69.85 & 72.44 & 72.67 & 70.07 & 71.38 & 74.04 & 73.05 & 70.07 \\
\hline & Freq & 2959 & 629 & 1880 & 328 & 2931 & 621 & 1879 & 328 \\
\hline \multirow[t]{3}{*}{1995} & Median & 48.17 & 38.81 & 53.92 & 37.42 & 53.65 & 41.04 & 54.64 & 37.9 \\
\hline & Mean & 50.57 & 38.19 & 58.68 & 37.33 & 57.66 & 40.56 & 60.09 & 37.61 \\
\hline & Freq & 2999 & 600 & 1868 & 328 & 2954 & 586 & 1866 & 328 \\
\hline \multirow[t]{3}{*}{2008} & Median & 63.82 & 41.98 & 59.67 & 39.35 & 65.99 & 43.26 & 59.82 & 39.38 \\
\hline & Mean & 66.6 & 41.43 & 65.65 & 39.36 & 69.07 & 43.02 & 66.31 & 39.53 \\
\hline & Freq & 2888 & 598 & 1858 & 328 & 2864 & 584 & 1857 & 328 \\
\hline 2008 & Median & 76.35 & 55.35 & 70.92 & 51.25 & 78.91 & 57.16 & 71.11 & 51.28 \\
\hline \multirow[t]{2}{*}{ I+II pillar } & Mean & 79.78 & 54.79 & 77.90 & 51.32 & 82.80 & 56.96 & 78.68 & 51.55 \\
\hline & Freq & 2888 & 598 & 1858 & 328 & 2864 & 584 & 1857 & 328 \\
\hline
\end{tabular}

Right after the introduction of the NDC system, adequacy concerns induced legislation to stimulate the contribution to a second pillar component. Adhesion to the second pillar (that we apply to workers under the 2008 reform only) can help in maintaining adequate pensions because of both the flows of additional contributions and the higher expected rate of return granted by the pension funds with respect to the public system (2 percent market rate versus 1.5 percent economic growth). Under the hypothesis of a contribution rate of 6.91 percent of the working income, the additional RR granted is around 12-14 pp of the last income. As reported in Table 4, the optimal comprehensive RR (first plus second pillar, RR1 + RR2) would then attain a level of about 71-79 percent for female and male private employees and 51-57 percent for the self-employed. Of course, this comes at the price of renouncing the option of receiving severance pay as a lump sum at 
retirement and of being fully in charge of the financial risk characterising the second pillar. The first official data after the reform, however, show that participation in the second pillar has been quite limited: The adhesion rate of employees in 2007 was 24.9 percent and the total number of participants, including the self-employed, was only 4.5 million (Covip, 2008).

The RRs reported in Table 4 are gross of income and payroll taxes. The payroll tax rate is, however, very different for the two categories of workers considered. As already mentioned, private employees are subject to a payroll tax equal to 33 percent of their gross wage; however, only one-third of the burden is in the worker's charge since the remaining two-thirds are paid by employers; that is, the payroll tax in the employer's charge constitutes a sort of extra payment, not accounted for in the gross wages ${ }^{11}$. Selfemployed workers are instead subject to a payroll tax rate of 20 percent of their income, obviously fully in their charge.

If we compute the RRs on income net of the contributions paid by the worker (that is, gross of income tax only), we then expect a general increase in their level and a reduction in the difference between the RRs of private employees and the self-employed. As reported in Table 5, the median comprehensive (first plus second pillar) minimum RRs under the 2008 reforms become equal to 85.8 and 79.7 percent for male and female private employees, respectively, and 68.3 and 63.3 percent for male and female selfemployed, respectively. The optimal RR depicted in the behavioural scenario rises to 88.7 and 79.9 percent for male and female private employees, respectively, and to 70.6 and 63.3 for male and female self-employed, respectively.

\footnotetext{
11 That is, given a gross wage of 100 euro, the labour cost to the firm is 122 while the wage net of payroll taxes is 89 euro.
} 
Table 5. Net RRs (no payroll taxes).

\begin{tabular}{|c|c|c|c|c|c|c|c|c|c|}
\hline & & \multicolumn{4}{|c|}{ Nonbehavioural } & \multicolumn{4}{|c|}{ Behavioural } \\
\hline & & \multicolumn{2}{|c|}{ Men } & \multicolumn{2}{|c|}{ Women } & \multicolumn{2}{|c|}{ Men } & \multicolumn{2}{|c|}{ Women } \\
\hline & & Private & Self & Private & Self & Private & Self & Private & Self \\
\hline \multirow[t]{3}{*}{ Pre-1992 } & Median & 74.58 & 86.23 & 71.06 & 82.95 & 75.56 & 89.72 & 72.57 & 83.39 \\
\hline & Mean & 75.20 & 85.68 & 75.24 & 83.58 & 76.16 & 89.90 & 77.01 & 84.22 \\
\hline & Freq & 2983 & 629 & 1888 & 328 & 2967 & 613 & 1886 & 328 \\
\hline \multirow[t]{3}{*}{1992} & Median & 77.38 & 90.10 & 77.58 & 86.36 & 78.92 & 90.72 & 77.77 & 86.14 \\
\hline & Mean & 78.48 & 89.43 & 81.65 & 86.51 & 80.20 & 91.41 & 82.08 & 86.50 \\
\hline & Freq & 2959 & 629 & 1880 & 328 & 2931 & 621 & 1879 & 328 \\
\hline \multirow[t]{3}{*}{1995} & Median & 54.13 & 47.91 & 60.59 & 46.20 & 60.28 & 50.67 & 61.40 & 46.78 \\
\hline & Mean & 56.82 & 47.15 & 65.94 & 46.09 & 64.79 & 50.08 & 67.52 & 46.43 \\
\hline & Freq & 2999 & 600 & 1868 & 328 & 2954 & 586 & 1866 & 328 \\
\hline \multirow[t]{3}{*}{2008} & Median & 71.71 & 51.83 & 67.04 & 48.58 & 74.14 & 53.41 & 67.22 & 48.62 \\
\hline & Mean & 74.83 & 51.15 & 73.77 & 48.59 & 77.61 & 53.11 & 74.51 & 48.81 \\
\hline & Freq & 2888 & 598 & 1858 & 328 & 2864 & 584 & 1857 & 328 \\
\hline 2008 & Median & 85.79 & 68.34 & 79.68 & 63.27 & 88.67 & 70.56 & 79.89 & 63.31 \\
\hline \multirow[t]{2}{*}{ (I+II pillar) } & Mean & 89.64 & 67.64 & 87.53 & 63.36 & 93.03 & 70.32 & 88.41 & 63.65 \\
\hline & Freq & 2888 & 598 & 1858 & 328 & 2864 & 584 & 1857 & 328 \\
\hline
\end{tabular}

\subsection{Assessing the pension system's distributive properties}

To synthesise the pension systems' distributive impact, Table 6 reports the PVR and Table 7 shows the RS index. 
Table 6. Median PVR by gender, scheme, and income quartiles - behavioural scenario.

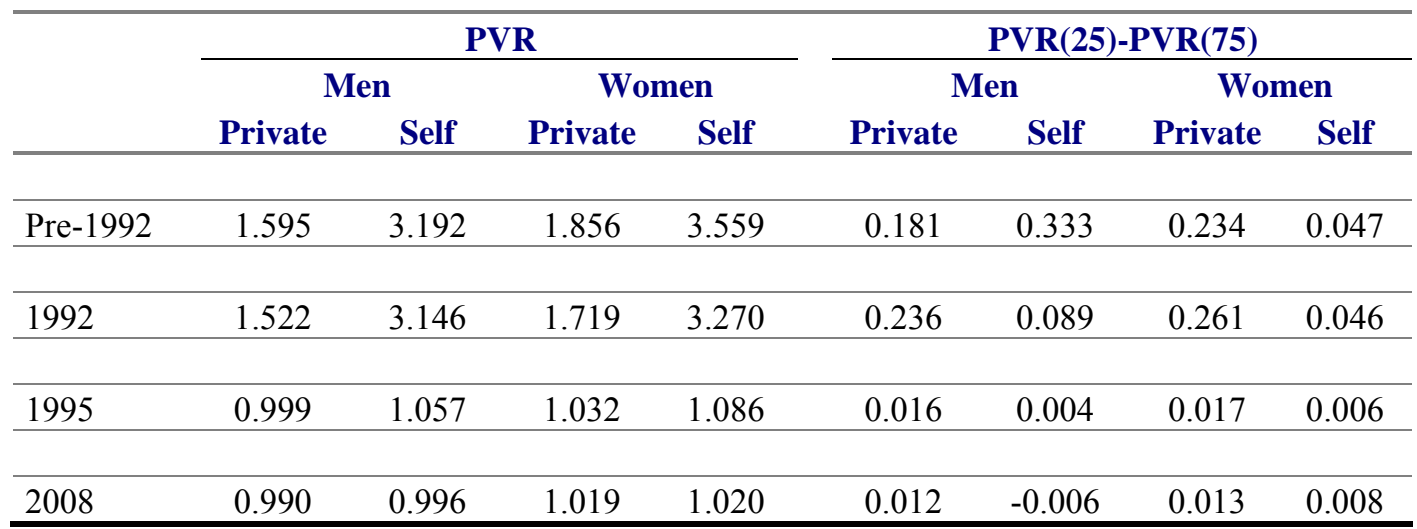

Note: PVR is the present value ratio, the ratio between the present value of the benefits that the worker will receive in the future and the present value of the contribution paid during his working life, both valued at retirement. The income quartiles are determined on the basis of the lifetime labour income valued at birth. The PVR for the lowest income quartile is PVR(25) while the PVR for the highest one is PVR(75).

The pre-1992 Italian pension system was highly generous and highly redistributive. As shown in Borella and Coda Moscarola (2006), such a redistribution was both good — that is, directed towards low-income individuals — and bad — that is, directed towards high-income individuals. The NDC system will instead be almost actuarially fair, granting an internal rate of return of about 1.5 percent in real terms ${ }^{12}$ and cancelling out almost all the redistribution. As shown in the left panel of Table 6 , in the pre-reform system the PVR of private employees is around 1.6-1.9 and that for the selfemployed is around 3.2-3.6. In other words, that DB system is granting benefits to workers about two to three times higher than what they paid in terms of contributions. Under the NDC systems (1995 and 2008) the PVR decreases instead for all categories to values ranging between 0.99 and 1.2 , that is, it is very close to the actuarial equality between contributions paid and benefits received.

The second panel of Table 6 shows the difference between the average PVR in the lowest and in the highest income quartile. In the pre-1992 system, such a difference for private employees is about $23 \mathrm{pp}$ for women and $18 \mathrm{pp}$ for men. For self-employed men this difference is even higher, at $33 \mathrm{pp}$, while for women, on the contrary, it is only about

\footnotetext{
12 The return equals the expected value of the long-term real GDP growth embedded in the annuity rates formula stated by 1995 reform.
} 
$5 \mathrm{pp}$. This is a consequence of the fact that in the pre-1992 system the PVR granted to self-employed women was quite high at all lifetime income levels.

The 2008 system, despite the general reduction in redistributive impact, is also slightly progressive thanks to the minimum old-age allowance to which low-income pensioners are entitled. The gap in the PVR of employees in the lowest income quartile with respect to that in the highest income quartile is $1.2-1.3 \mathrm{pp}$. For the self-employed it is instead virtually equal to zero; more precisely, for men it is slightly negative, meaning that the system becomes somewhat regressive for them.

Table 7 reports the RS index that measures the (eventual) reduction in the income concentration index brought on by the pension system. A positive RS index indicates that the pension system is redistributing from the rich to the poor, since it reduces lifetime income inequality.

Table 7. Gini indexes under the current regime and in the absence of any regime and RS index by reforms $(* 100)$ — behavioural scenario.

\begin{tabular}{lc}
\hline Reform & RS index $\left(\boldsymbol{*}^{\mathbf{1 0 0})}\right.$ \\
\hline Pre-1992 & 2.33 \\
\hline 1992 & 2.70 \\
\hline 1995 & 0.34 \\
\hline 2008 & 0.26 \\
\hline $\begin{array}{l}\text { Note: The Gini index is computed on lifetime resources (earnings gross of income and payroll tax, plus } \\
\text { gross benefits), valued at time zero. 'Gini, no social security' is computed on permanent labour income } \\
\text { (gross of income and payroll taxes) only, also valued at birth. }\end{array}$
\end{tabular}

The overall effect of the first pillar pension system in reducing the income concentration index ranges between 2.33 and $2.70 \mathrm{pp}$ in the DB systems (i.e., pre-1992 and 1992 systems), while it is negligible under the NDC systems (0.34 and 0.26 in 1995 and 2008). The second pillar, being actuarially fair, grants a PVR equal to 1 (and for this reason it is not reported in the tables of this section) and, given the hypothesis about the equality of the contribution rate among different schemes, does not change the overall redistributive impact of the pension system. Finally, the results show that convenience in participation and the redistributive impact of the pension systems do not change substantially between 
the behavioural and nonbehavioural scenarios. Both the average PVR and the RS vary only slightly when individuals optimally choose their retirement age instead of retiring as soon as eligible.

\section{Conclusions}

This paper contributes to the literature on the adequacy and redistribution of pension systems. We focus on the case of Italy, since it underwent three main pension reforms during last 20 years with the aim of recovering long-term financial sustainability. Italy shifted from a generous DB system - characterised by a short period for computing pensionable earnings and very low age/seniority requirements to attain eligibility - to a stricter DB - with a longer reference period for the computation of pensionable earnings and higher age/seniority eligibility requirements. Italy then designed an actuarially fair NDC system with flexible access to retirement - from the ages of 57 to 65 - and, finally, shifted to a modified NDC with stricter age/seniority requirements. In particular, the effects of this last, 2008 reform have not been studied much.

We approached the problem by adopting a microsimulation perspective. We built CeRPSIM2, an upgrade of our previous cohort dynamic microsimulation model (Borella and Coda Moscarola, 2006), in which we accounted for optimality in the individual choice of retirement age by including a behavioural rule for retirement. We then simulated the effects of different pension systems - as shaped by the various Italian reforms - on a cohort of young individuals, born in 1995. We modelled retirement according to two different rules: a non-behavioural approach, in which workers retire as soon as they become eligible, and a behavioural approach, in which workers retire when their utility is at a maximum.

The comparison between the behavioural and nonbehavioural approaches in modelling retirement decisions allows us to better infer many consequences of the various pension systems. It is a common perception that shifting from a generous DB system to an NDC system induces individuals to postpone retirement in order to preserve the adequacy of their pension benefits. Our research confirmed this but also highlighted two additional and probably lesser known facts. Actually, the pre-reform scenario already contained incentives for some categories to postpone retirement. This was the case, in 
particular, for self-employed men who, despite the generosity of the pre-reform pension rule, were entitled to low pensions and postponed retirement for adequacy reasons. Second, women tend to always postpone less than men, demonstrating a higher preference for nonworking time. The absence of any intervention policy to help women in child care or adult care duties may be a cause. The ages around retirement are indeed the ones where the risk of having to provide care to elderly parents or look after grandchildren is highest.

By tightening eligibility requirements, the 2008 reform is expected to be binding for private employees, whose optimal retirement age under the 1995 system is lower than the minimum retirement age required after the 2008 reform. It is not binding, however, for the self-employed, for whom it is convenient anyway to postpone retirement in order to access to higher transfers. Concerning the adequacy of benefits, we found that voluntary postponement of retirement and, above all, participation in the second pillar would grant a comprehensive RR (first plus second pillars) comparable to the ones obtained from the sole first pillar in the pre-reform regime. Of course, this comes at the cost of renouncing severance pay and accepting the financial risk characterising pension funds.

Finally, conclusions about the redistributive impact of the pension system change only slightly when comparing the nonbehavioural and behavioural scenarios. The prereform DB system is far more generous and redistributive than the NDC one; however, the pre-1992 social security system had a small impact in modifying the Gini concentration index of lifetime income, indicating that the system was only moderately progressive. The NDC system, being inspired to actuarial fairness, has instead almost no effect on lifetime income distribution. 


\section{References}

Alessie, R., and M. Belloni (2009), 'The Importance of Financial Incentives on Retirement Choices: New Evidence for Italy', Labour Economics, forthcoming.

Baker, M., J. Gruber, and K. Milligan (2003), 'The Retirement Incentive Effects of Canada's Income Security Programs', Canadian Journal of Economics, vol. 36, 2, pp. 261-290.

Blundell, R., C. Meghir, and S. Smiths (2002), 'Pensions Incentives and the Patterns of Early Retirement', Economic Journal, vol. 112, pp. 153-170.

Borella, M. (2004), 'The Error Structure of Earnings: An Analysis on Italian Longitudinal Data', Rivista Internazionale di Scienze Economiche e Commerciali/ International Review of Economics and Business, vol. 51(3), pp. 405-422.

Borella, M., and F. Coda Moscarola (2006), 'Distributive Properties of Pension Systems: A Simulation of the Italian Transition from Defined Benefit to Notional Defined Contribution', Giornale degli Economisti e Annali di Economia, vol. 65(1), May 2006.

Borella, M., and E. Fornero (2009), 'Adequacy of pension systems in Europe: An analysis based on comprehensive replacement rates', paper prepared for the AIM project, forthcoming as ENEPRI Report 2009.

Bourguignon, F., and A. Spadaro (2006), 'Microsimulation as a Tool for Evaluating Redistribution Policies', Journal of Economic Inequality, vol. 4(1), pp. 77-106.

Coile, C., and J. Gruber (2000), 'Social Security Incentives for Retirement', Working Paper 7651, Cambridge, MA: National Bureau of Economic Research.

Covip (2008), 'Relazione per l'anno 2007', Commissione Vigilanza per i Fondi Pensione, Rome.

Creedy, J., and G. Kalb (2006), 'Labour Supply and Microsimulation: The Evaluation of Tax Policy Reforms', Edward Elgar, Cheltenham.

Dekkers, G., H. Buslei, M. Cozzolino, R. Desmet, J. Geyer, D. Hofmann, M. Raitano, V. Steiner, P. Tanda, S. Tedeschi, and F. Verschueren (2009), 'What Are the Consequences of the AWG-Projections for the Adequacy of Social Security Pensions ? An Application of the Dynamic Micro Simulation Model MIDAS for Belgium, Italy and Germany, ENEPRI Research Report n.65, AIM WP4.

Eurostat (2009), 'Living Conditions and Welfare', http://epp.eurostat.ec.europa.eu.

Feldstein, M., and J. B. Liebman (2002), 'The Distributional Aspects of Social Security and Social Security Reform', University of Chicago, Chicago.

Friedberg, L., and A. Webb (2005), 'Retirement and the Evolution of Pension Structure', Journal of Human Resources, vol. 40(2), pp. 281-308.

Gruber, J., and D. Wise (2004), 'Social Security Programs and Retirements Around the World, NBER, University of Chicago', Chicago.

ISTAT (2003a), ‘Annuario Statistico Italiano 2003’, Roma. 
ISTAT (2003b), 'Rilevazione Trimestrale sulle Forze di Lavoro', Roma.

Mazzaferro, C., and M. Morciano (2005), 'Un Modello di Microsimulazione Dinamica per la Stima della Riforma Pensionistica', Paper prepared for the SIEPAnnual Conference 'Politiche Pubbliche, Sviluppo e Crescita', University of PAVIA.

Reynolds, M.O., and E. Smolensky (1977), 'Post-Fisc Distributions of Income in 1950, 1961, and 1970', Public Finance Quarterly, vol. 5(4), pp. 419-438.

Richiardi, M., and R. Leombruni (2006), 'LABORsim: An Agent-Based Microsimulation of Labour Supply. An Application to Italy', Computational Economics, vol. 27(1), pp. 63-88.

Smith, J. P. (2003), 'Trends and Projections in Income Replacement During Retirement', Journal of Labor Economics, vol. 21(4), pp. 755-782. 


\section{Appendix - The microsimulation model}

CeRPSIM2 is a microsimulation model designed to analyse the distributional features embedded in the Italian pension system during its transition from a DB system to an NDC system. It is composed of three main modules: the population, pension, and retirement modules ${ }^{13}$.

\section{A1. The cohort population module}

The module includes a demographic section and a labour market section, which simulate all the main life events of individuals. Individuals' transitions across different states (marital status, labour status, etc.) are conditioned on individual socioeconomic characteristics and are modelled throughout a Monte Carlo procedure, that is, they are evaluated by performing a random draw from a uniform distribution and comparing it to the relevant probability taken from available sociodemographic surveys or from national statistics data. If the value of the draw is higher than the sample probability, the individual changes his status; if not, the individual remains in the initial state.

Once individuals are born, their lives evolve according to various routines which determine the day and month of birth, gender, region of residence, performance in the labour market, family status, and survival. We illustrate these routines in turn after briefly describing the data sources used.

\section{A1.1. Data sources}

Transition probabilities are drawn from the national statistics (Istituto Nazionale di Statistica, ISTAT) data and from two national micro datasets: the Bank of Italy's Survey of Households' Income and Wealth (SHIW) and a sample of administrative data drawn from the main social security scheme (Istituto Nazionale di Previdenza Sociale, INPS) archive.

The INPS archive officially records the complete earnings and contribution histories of all participants, that is, employees in the private sector and some categories of self-employed (craftsmen, tradesmen, and farmers). The available sample is formed by all individuals born on March 5 - so that the theoretical sample frequency is 1:365 - and reports employment spells from 1985 to 1998 . The archive contains very rich information about the earnings histories of the workers, recording spells of unemployment as well as labour income earned each year.

As typical with administrative data, demographic information is, on the other hand, less rich: The sample records the date and province of birth of the worker, as well as gender. No information about family status is available, or about the education level of the worker. For this reason we complement it with information contained in the SHIW, which is run about every two years since 1989 to 2006 on a representative sample of Italian households.

\section{A1.2. Life-invariant characteristics}

At the beginning of the simulation of each cohort, a user-set number of individuals aged 0 are created. The life-invariant characteristics routine randomly assigns each individual a date of birth, gender, and region of residence through a Monte Carlo procedure. In each cohort the date of birth is uniformly distributed through the year: This feature of the program allows one to

\footnotetext{
13 This is an upgraded version of the appendix in Borella and Coda Moscarola (2006).
} 
accurately model the moment when a worker is eligible to claim a pension benefit according to the so-called exit windows (which are indeed linked to the date of birth). Gender and region of residence are randomly assigned according to the gender and the regional distribution of newborn in the year 2002 (ISTAT, 2003a).

Table A1. Gender and region of residence incidence.

Newborn males incidence

$51.25 \%$

Dwelling place incidence

$\begin{array}{ll}\text { North } & 44.87 \% \\ \text { Centre } & 19.15 \% \\ \text { South } & 35.98 \%\end{array}$

Source: ISTAT, 2003a.

\section{A1.3. Mortality}

In each time period every individual enters the mortality subroutine, which determines whether that individual will survive or not in the simulated time period on the basis of genderspecific mortality tables. Individuals who are predicted to die in the simulated year still enter all subsequent routines until the cycle for the year in progress is completed. Afterwards, they are recorded as dead and are no longer taken into account in the population routines.

All our simulations are based on RG48 mortality tables. These are cohort mortality tables elaborated by the State General Accounting Department (Ragioneria Generale dello Stato, RGS). They originally refer to the cohort born in 1948 but can be extended to future cohorts by the provided age-shifting formulas.

\section{A1.4. Education}

In the program, individuals are forced into school until they turn 17 (that is, they complete compulsory education). As recorded in the SHIW, the fraction of individuals who do not complete compulsory education for cohorts born after 1950 is low and tends to 0 for younger cohorts. In addition, according to Italian legislation, individuals cannot work before reaching the age of 16, which means that they cannot start contributing into the pension system before then.

After completion of compulsory schooling, the individual decides whether to continue studying or not. The routine models this decision as a random process and the probabilities of getting a higher degree or a university degree are derived from the SHIW data. We assume that the 1995 cohort, whose behaviour is currently unobservable, will reproduce the same education shares of cohorts born between 1960 and 1979. Frequencies are allowed to vary according to gender and region of residence (north, centre, or south).

We do not account for school dropouts and once an individual decides to start a cycle of study, he or she completes it. This hypothesis is forced by SHIW data, which only report the highest educational degree achieved by each individual. Individuals who choose not to continue studying and individuals who complete their college enter the participation routine ${ }^{14}$.

14 Postgraduate education in Italy is still quite limited and is not modelled. 
Table A2. Education level by gender, region, and cohort (percentage).

$\begin{array}{lcccccc} & \text { North } & \begin{array}{c}\text { Males } \\ \text { Centre }\end{array} & \text { South } & \text { North } & \begin{array}{c}\text { Females } \\ \text { Centre }\end{array} & \text { South } \\ \begin{array}{lccccc}\text { Cohort 1960-1979 } \\ \text { Compulsory school }\end{array} & 38.4 & 38.1 & 49.1 & 32.9 & 33.9 & 47.5 \\ \text { High school } & 48.0 & 48.6 & 39.2 & 51.0 & 50.3 & 36.5 \\ \text { College } & 13.6 & 13.3 & 11.7 & 16.1 & 15.7 & 16.0\end{array}$

Source: SHIW, 2004-2006.

\section{A1.5. Participation}

When individuals choose to no longer be students (or are forced to quit school by the program because they are university graduates), they decide whether or not to enter the labour force. This decision is modelled as a once and for all choice: if an individual decides to enter the labour force, that individual will remain active in the labour market until retirement (or death), possibly facing spells of unemployment. On the other hand, if an individual decides not to enter the labour force, he or she will remain forever out of it.

Participation rates are specific for cohorts (born before and after 1968), gender, and region and refer to the year 2002 (ISTAT, 2003b).

Table A3. Participation rates by cohort, gender, and region (percentage).

\begin{tabular}{lllllccc} 
& \multicolumn{3}{c}{ Men } & \multicolumn{3}{c}{ Women } \\
& \multicolumn{1}{c}{ North Centre South } & North & Centre & South \\
Cohorts born in 1968 or before & 0.95 & 0.94 & 0.91 & 0.68 & 0.63 & 0.43 \\
Cohorts born after 1968 & 0.95 & 0.94 & 0.91 & 0.79 & 0.68 & 0.46
\end{tabular}

Source: ISTAT, 2003b.

\section{A1.6. First job}

An individual joining the labour force for the first time enters the first-job routine. According to the observed probabilities, the individual can succeed in finding a first job in the current year. If a job is not found, the individual is recorded as not employed and will re-enter this routine in the following time periods. The probability of finding a first occupation is drawn from SHIW data for the only cohort for which this kind of information is available (individuals born between 1970 and 1979). We assume the same probabilities apply to the 1995 cohort. The probabilities also vary according to age class (younger or older than 24 years), gender, and region of residence (north, centre, and south). As the probabilities vary according to age class, we implicitly take into account the education level (college graduates enter the labour force after they turn 24). 
Table A4. Probability of unemployment conditional on looking for a first job (percentage).

$\begin{array}{lcc}\text { Males } & \begin{array}{c}\text { Younger than } \\ \text { 24 years }\end{array} & \begin{array}{c}24 \text { years or } \\ \text { older }\end{array} \\ \begin{array}{lcc}\text { Cohort } 70-79 & \\ \text { North } & 9.2 & 5.3 \\ \text { Centre } & 24.9 & 13.3 \\ \text { South } & 51.2 & 32.2 \\ & & \\ \text { Females } & & \\ & \text { Younger than } & 24 \text { years or } \\ \text { older }\end{array} \\ \text { Cohort } 70-79 & 24 \text { years } & \\ \text { North } & & 6.8 \\ \text { Centre } & 18.0 & 16.5 \\ \text { South } & 27.9 & 47.8 \\ \text { Source: SHIW, various years. } & 66.5 & \end{array}$

\section{A1.7. Kind of employment and social security scheme}

Once an individual finds an occupation, he or she is randomly assigned to a social security scheme and a professional qualification. These characteristics do not change throughout the individual's lifetime.

The assignment of the social security scheme proceeds in two steps: A first random draw determines to which of three main schemes the worker belongs: private sector employees), public sector employees, or self-employed. The relevant probabilities, computed from the SHIW data, vary according to region of residence (north, centre, or south), education level (mandatory school, high school, or university degree), gender, and cohort (born before or after 1960).

A second random draw determines the social security sub-scheme to which the worker belongs, when relevant: 'regular' private sector employee ( 86.7 percent or agricultural worker (13.3 percent) if the main scheme is private sector employee and craftsman (40 percent), tradesman (40 percent), or farmer (20 percent) if the main scheme is self-employed. The appropriate frequencies are computed from our administrative data sample. Although a variety of different social security sub-schemes also exist in the public sector, all public workers are modelled as belonging to the main sub-scheme ${ }^{15}$.

A third random draw determines, where relevant, whether the individual is white collar or blue collar, conditional on the individual's scheme. Individuals who start working before age 18 are registered as blue collar, individuals who start working after that age have a probability of 35 percent of being blue collar in the private sector and of 10 percent of being blue collar in the public one ${ }^{16}$. These frequencies are computed from the administrative data (SHIW for public sector workers) without any further sub-grouping, since the number of observations at this level of disaggregation is limited.

\footnotetext{
15 That is, the sub-scheme for local government employees (CPDEL).

16 According to both administrative data and the SHIW sample, blue collar workers are about 70 percent of all workers employed in the private sector, irrespective of their age at entry into the labour market. As for the public sector, according to the SHIW sample, blue collar workers comprise about 20 percent.
} 


\section{A1.8. Number of weeks}

Conditional on having a job and on the number of weeks worked in the previous year, this routine determines the number of weeks worked.

We compute sample frequencies separately for private employees and employees in the agricultural sector. To do so, we take two steps: We first discretise the number of weeks worked each year in our administrative panel into six classes $(0,1-13,14-26,27-39,40-47,48-52)$ and then we compute transition probabilities for each age class (16-24, 25-34 and 35-64) and for each region (north, centre, and south).

For the self-employed, we assume that, conditional on working, they work 52 weeks per year ${ }^{17}$. Using our administrative sample, we compute the probabilities of being unemployed conditional on the past year's employment status. These probabilities vary according to age (in classes), gender, and region of residence ${ }^{18}$.

Public sector employees do not face unemployment spells: on the one hand, we lack data to compute unemployment probabilities for this group of workers; on the other, it seems a reasonable assumption given the stability of work relationships in the Italian public sector.

\section{A1.9. Earnings}

Earnings profiles have been estimated on administrative data separately for private sector and self-employed workers, men and women, white and blue collar ${ }^{19}$.

The estimated equation is

$$
\begin{aligned}
& \ln y_{i t}=x_{i t} \beta+\gamma_{i}+\varepsilon_{i t} \\
& \varepsilon_{i t}=\rho \varepsilon_{i t-1}+\eta_{i t} \\
& \gamma_{i} \sim\left(0, \sigma_{\gamma}^{2}\right) ; \quad \eta_{i t} \sim\left(0, \sigma_{\eta}^{2}\right)
\end{aligned}
$$

where $x_{i t}$ is a vector of individual characteristics, including a constant, a polynomial in age (third degree for self-employed, fourth degree for employees), cohort dummies (cohorts 1935, 1945, 1955, 1965, 1975), regional dummies (north, centre, south), and time dummies, which are assumed to sum to zero and be orthogonal to a time trend.

The unobserved component is assumed to be the sum of a random effect $\left(\gamma_{i}\right)$ which does not vary over time and is uncorrelated with the explanatory variables included in the equation, plus an AR(1) component with parameter $\rho$. The AR(1) process plus an individual random effect has been found to be a good characterisation of the unobserved component of earnings in Italy in previous work (Borella, 2004).

\footnotetext{
17 According to our administrative data, the fraction of self-employed working less than a full year is negligible and we do not model it.

${ }_{18}$ Due to sample size, the probability of being employed conditional on being unemployed in the previous year varies only according to age class and gender.

19 The self-employed are further differentiated into craftsmen and tradesmen, excluding farmers. In our administrative sample farmers who do not report zero income are fewer than 5 percent, resulting in a sample size too small to estimate the income profile. The zero-income report is mainly due to the pension legislation which requires a minimum payroll tax to be paid up to a threshold. All farmers with incomes below that threshold (i.e., the vast majority) report zero income and pay the minimum payroll tax.
} 
In the microsimulation model, each individual is given an average log earnings profile for his or her age and group (defined by cohort, gender, region, and occupation) plus an error term formed by the sum of the two unobserved components. The first one is drawn from a normal distribution with variance $\sigma_{\gamma}^{2}$ at the beginning of active life and it permanently shifts up or down the average profile for the individual to whom it refers. The second component, which is also individual specific and varies over time, is formed by the shock from the previous period times the autoregressive parameter $\rho$ plus an error term drawn from a normal distribution with variance $\sigma_{\eta}^{2}$

Table A5. Estimates for unobserved error components.

\begin{tabular}{lcccccc} 
& \multicolumn{3}{c}{ Males } & \multicolumn{3}{c}{ Females } \\
& $\begin{array}{c}\text { Blu } \\
\text { collar }\end{array}$ & $\begin{array}{c}\text { White } \\
\text { collar }\end{array}$ & $\begin{array}{c}\text { Self- } \\
\text { employed }\end{array}$ & $\begin{array}{c}\text { Blu } \\
\text { collar }\end{array}$ & $\begin{array}{c}\text { White } \\
\text { collar }\end{array}$ & $\begin{array}{c}\text { Self- } \\
\text { employed }\end{array}$ \\
$\rho$ & 0.432 & 0.529 & 0.165 & 0.419 & 0.440 & 0.070 \\
$\sigma_{\eta}$ & 0.126 & 0.110 & 0.313 & 0.175 & 0.162 & 0.309 \\
$\sigma_{\gamma}$ & 0.242 & 0.335 & 0.263 & 0.332 & 0.360 & 0.229
\end{tabular}

\section{A1.10. Marital status}

In this routine individuals are recorded as children (as opposed to heads of households) until they finish their schooling years. When they are between 14 and 50 years of age, provided they are no longer students, they may get married according to the gender- and age-specific probabilities available from the 1991 census data. Conditional on being married, an individual faces the possibility of becoming divorced (probabilities also available from 1991 census data) or widowed according to the mortality table used in the program. It should be noted that we do not explicitly model the spouse or his or her income. Marital status becomes relevant, however, when computing individual social security wealth.

\section{A2. The pension module}

The pension module is a very detailed module able to compute pensionable earnings and contributions paid, check the eligibility requirements, and compute the pension benefit for a number of schemes and for different regimes. Pension benefits of the first and second pillars are computed for individuals who retire from the year 2000 onwards.

The program is able to replicate the pre-1992-reform regime as well as each of the subsequent reforms, up to 2008. As described in the main text, the most important ones are (1) the 1992 reform, which modified the DB regime, (2) the 1995 reform, which introduced the NDC scheme, and (3) the 2008 reform, which tightened eligibility requirements. In addition, the same module computes the minimum pension - applying to retirees in the DB system — and old-age income maintenance - applying to nonretirees in the DB system and to all individuals in the NDC scheme.

The schemes covered, as already mentioned, are private sector employees, employees in the agricultural sector, public sector employees, and the self-employed, the latter categorized into craftsmen, tradesmen, farmers, and farmers in disadvantaged regions. All these schemes greatly 
differed in eligibility rules, payroll taxes and the computation of benefits until the 1995 reform imposed uniformity. The equalising process, which has been gradual, is at present almost complete. Differences in the definition of pensionable earnings (or income) and in payroll tax rates are nonetheless also maintained in the future.

This module further computes for each individual the present value of payroll taxes paid during the whole working life and the present value of the pension benefits to be received. These two quantities are the building blocks for various money's worth measures used in both the retirement module and our analysis. Finally, this module computes a measure of permanent income, defined as the present value at birth of lifetime working incomes.

\section{A3. The retirement module}

This module is able to simulate the retirement decisions of individuals according to two alternative criteria.

According to what we named the nonbehavioural scenario, individuals are assumed to claim their pension benefits as soon as they are eligible. This requires not only that they meet the minimum eligibility requirement but also that they wait for an exit window to become active ${ }^{20}$.

Second, we model retirement behaviour in a probabilistic way using the coefficients of the probit estimates by Alessie and Belloni (2009). Their estimates are based on a sample of Italian administrative data (such as the one we use to estimate earnings profiles) which includes complementary files. The strength of their work lies in the availability in their data of actual seniority at retirement: This information allows one to precisely estimate the effect of money's worth measures on the probability of retirement. The authors use data covering the period 19852000 and provide separate estimates for males and females. The main money's worth measures used in these estimates are the present value of pension benefits (PVB) and the peak value (PV), defined as the maximum forecasted accrual at each age. In particular, the present value of pension benefits for an individual of age $a$ evaluating retirement at the same age $a$ is defined as

$$
P V B_{a, a}=\sum_{s=a+1}^{T} \rho(s) B_{a}(s)
$$

where $T$ is the life span, $\rho$ is the discount factor at age $s$ (which includes the real interest rate, the conditional survival probability, and accounts for survivor benefits), and $B(s)$ is the pension benefit received at age $s$. The present value of benefits for a worker of age $a$ who evaluates retirement at a subsequent age $h$ takes into account the contributions that are still to be paid:

$$
P V B_{a, h}=\sum_{s=h+1}^{T} \rho(s) B_{h}(s)-\sum_{s=a+1}^{h} \rho^{\prime}(s) c(s)
$$

where the discount factor used for contributions $\rho^{\prime}$ includes the real interest rate and the conditional survival probability. The peak value, used as a measure of marginal incentive in the probit specification, is defined as

$$
P V_{a}=\max \left(P V B_{a, h}-P V B_{a, a}\right) \quad h=a+1, \ldots, R
$$

\footnotetext{
${ }^{20}$ Workers eligible to claim a pension can retire only in certain predetermined periods during the year (the socalled exit windows).
} 
that is, the maximum accrual forecast at age $a$ up to the maximum age of retirement $R$ - assumed to be 70 years both in Alessie and Belloni (2009) and in our simulations.

Since Alessie and Belloni's (2009) estimates are based on PVB and PV evaluated in 2006, while our workers are born in 1995 and retire after 2030, we scale back to 2006 our PVB and PV measures (as well as other monetary variables) in order to take into account inflation and economic growth. Other covariates include occupation and geographical area; the coefficients we use are reported in the next table.

Table A6. Probit estimates for the probability of retirement.

\begin{tabular}{|l|c|c|}
\hline Variable & Males & Females \\
\hline PVB & 0.0201566 & -0.0169801 \\
PV & -0.1804432 & -0.2360941 \\
Earnings & -0.5205978 & -0.506908 \\
Age & 0.1084939 & 0.2555567 \\
PVB_0 & 0.0158636 & 0.0451497 \\
PV_0 & 0.0263811 & 0.0562307 \\
White collar & -0.0399982 & -0.0858914 \\
Manager & -0.2653279 & -0.065222 \\
North-east & -0.1028228 & -0.1451506 \\
Centre & -0.2145893 & -0.162346 \\
South & -0.2573966 & -0.1344933 \\
Cohort (average) & 0.1752371 & 0.133720814 \\
Industry (average) & -0.23174075 & 0.011557756 \\
Constant & -6.635366 & -14.26158 \\
\hline$\sigma_{\alpha}$ & 0.187 & 0.209 \\
\hline
\end{tabular}

Note: Probit coefficients from Alessie and Belloni (2009): dependent variable $=1$ if a worker decides to retire, $=0$ otherwise; specification with $\mathrm{PV}$ and no age dummies. We use the average of the coefficients for the cohort as we have only a single cohort (not covered in the estimates) and we specify no industry in our artificial population. Here PVB_0 and PV_0 are the present value of benefits and the peak value in the first year of eligibility, respectively, and are included to account for the correlation between unobserved heterogeneity and explanatory variables (i.e., a quasi-fixed effect approach is used). The uncorrelated part of the unobserved heterogeneity is $\alpha$ with standard deviation $\sigma_{\alpha}$ reported in the table. 
Our papers can be downloaded at:

http://cerp.unito.it/publications

\section{CeRP Working Paper Series}

\begin{tabular}{|c|c|c|}
\hline $\mathrm{N}^{\circ} 1 / 00$ & Guido Menzio & Opting Out of Social Security over the Life Cycle \\
\hline$N^{\circ} 2 / 00$ & $\begin{array}{l}\text { Pier Marco Ferraresi } \\
\text { Elsa Fornero }\end{array}$ & $\begin{array}{l}\text { Social Security Transition in Italy: Costs, Distorsions and (some) } \\
\text { Possible Correction }\end{array}$ \\
\hline$N^{\circ} 3 / 00$ & $\begin{array}{l}\text { Emanuele Baldacci } \\
\text { Luca Inglese }\end{array}$ & $\begin{array}{l}\text { Le caratteristiche socio economiche dei pensionati in Italia. } \\
\text { Analisi della distribuzione dei redditi da pensione (only available } \\
\text { in the Italian version) }\end{array}$ \\
\hline$N^{\circ} 4 / 01$ & Peter Diamond & Towards an Optimal Social Security Design \\
\hline$N^{\circ} 5 / 01$ & Vincenzo Andrietti & $\begin{array}{l}\text { Occupational Pensions and Interfirm Job Mobility in the } \\
\text { European Union. Evidence from the ECHP Survey }\end{array}$ \\
\hline $\mathrm{N}^{\circ} 6 / 01$ & Flavia Coda Moscarola & $\begin{array}{l}\text { The Effects of Immigration Inflows on the Sustainability of the } \\
\text { Italian Welfare State }\end{array}$ \\
\hline$N^{\circ} 7 / 01$ & Margherita Borella & $\begin{array}{l}\text { The Error Structure of Earnings: an Analysis on Italian } \\
\text { Longitudinal Data }\end{array}$ \\
\hline$N^{\circ} 8 / 01$ & Margherita Borella & $\begin{array}{l}\text { Social Security Systems and the Distribution of Income: an } \\
\text { Application to the Italian Case }\end{array}$ \\
\hline$N^{\circ} 9 / 01$ & Hans Blommestein & $\begin{array}{l}\text { Ageing, Pension Reform, and Financial Market Implications in } \\
\text { the OECD Area }\end{array}$ \\
\hline$N^{\circ} 10 / 01$ & $\begin{array}{l}\text { Vincenzo Andrietti and Vincent } \\
\text { Hildebrand }\end{array}$ & $\begin{array}{l}\text { Pension Portability and Labour Mobility in the United States. } \\
\text { New Evidence from the SIPP Data }\end{array}$ \\
\hline$N^{\circ} 11 / 01$ & $\begin{array}{l}\text { Mara Faccio and Ameziane } \\
\text { Lasfer }\end{array}$ & $\begin{array}{l}\text { Institutional Shareholders and Corporate Governance: The Case } \\
\text { of UK Pension Funds }\end{array}$ \\
\hline$N^{\circ} 12 / 01$ & Roberta Romano & $\begin{array}{l}\text { Less is More: Making Shareholder Activism a Valuable } \\
\text { Mechanism of Corporate Governance }\end{array}$ \\
\hline$N^{\circ} 13 / 01$ & Michela Scatigna & Institutional Investors, Corporate Governance and Pension Funds \\
\hline$N^{\circ} 14 / 01$ & Thomas H. Noe & Investor Activism and Financial Market Structure \\
\hline$N^{\circ} 15 / 01$ & Estelle James & $\begin{array}{l}\text { How Can China Solve ist Old Age Security Problem? The } \\
\text { Interaction Between Pension, SOE and Financial Market Reform }\end{array}$ \\
\hline$N^{\circ} 16 / 01$ & $\begin{array}{l}\text { Estelle James and } \\
\text { Xue Song }\end{array}$ & $\begin{array}{l}\text { Annuities Markets Around the World: Money's Worth and Risk } \\
\text { Intermediation }\end{array}$ \\
\hline$N^{\circ} 17 / 02$ & $\begin{array}{l}\text { Richard Disney and } \\
\text { Sarah Smith }\end{array}$ & $\begin{array}{l}\text { The Labour Supply Effect of the Abolition of the Earnings Rule } \\
\text { for Older Workers in the United Kingdom }\end{array}$ \\
\hline $\mathrm{N}^{\circ} 18 / 02$ & Francesco Daveri & $\begin{array}{l}\text { Labor Taxes and Unemployment: a Survey of the Aggregate } \\
\text { Evidence }\end{array}$ \\
\hline$N^{\circ} 19 / 02$ & $\begin{array}{l}\text { Paolo Battocchio } \\
\text { Francesco Menoncin }\end{array}$ & $\begin{array}{l}\text { Optimal Portfolio Strategies with Stochastic Wage Income and } \\
\text { Inflation: The Case of a Defined Contribution Pension Plan }\end{array}$ \\
\hline$N^{\circ} 20 / 02$ & Mauro Mastrogiacomo & Dual Retirement in Italy and Expectations \\
\hline$N^{\circ} 21 / 02$ & $\begin{array}{l}\text { Olivia S. Mitchell } \\
\text { David McCarthy }\end{array}$ & Annuities for an Ageing World \\
\hline
\end{tabular}




\begin{tabular}{|c|c|}
\hline$N^{\circ} 22 / 02$ & $\begin{array}{l}\text { Chris Soares } \\
\text { Mark Warshawsky }\end{array}$ \\
\hline$N^{\circ} 23 / 02$ & Ermanno Pitacco \\
\hline$N^{\circ} 24 / 02$ & $\begin{array}{l}\text { Laura Ballotta } \\
\text { Steven Haberman }\end{array}$ \\
\hline$N^{\circ} 25 / 02$ & $\begin{array}{l}\text { Edmund Cannon } \\
\text { Ian Tonks }\end{array}$ \\
\hline$N^{\circ} 26 / 02$ & E. Philip Davis \\
\hline$N^{\circ} 27 / 02$ & Reinhold Schnabel \\
\hline$N^{\circ} 28 / 02$ & Luca Spataro \\
\hline$N^{\circ} 29 / 02$ & Marco Taboga \\
\hline$N^{\circ} 30 / 03$ & $\begin{array}{l}\text { Bas Arts } \\
\text { Elena Vigna }\end{array}$ \\
\hline$N^{\circ} 31 / 03$ & Giacomo Ponzetto \\
\hline$N^{\circ} 32 / 04$ & $\begin{array}{l}\text { Angelo Marano } \\
\text { Paolo Sestito }\end{array}$ \\
\hline$N^{\circ} 33 / 04$ & $\begin{array}{l}\text { Elsa Fornero } \\
\text { Carolina Fugazza } \\
\text { Giacomo Ponzetto }\end{array}$ \\
\hline $\mathrm{N}^{\circ} 34 / 04$ & Chourouk Houssi \\
\hline$N^{\circ} 35 / 04$ & $\begin{array}{l}\text { Monika Bütler } \\
\text { Olivia Huguenin } \\
\text { Federica Teppa }\end{array}$ \\
\hline$N^{\circ} 36 / 04$ & Laurence J. Kotlikoff \\
\hline$N^{\circ} 37 / 04$ & Jay Ginn \\
\hline$N^{\circ} 38 / 05$ & $\begin{array}{l}\text { Carolina Fugazza } \\
\text { Federica Teppa }\end{array}$ \\
\hline$N^{\circ} 39 / 05$ & Anna Rita Bacinello \\
\hline$N^{\circ} 40 / 05$ & $\begin{array}{l}\text { Carolina Fugazza } \\
\text { Massimo Guidolin } \\
\text { Giovanna Nicodano }\end{array}$ \\
\hline $\mathrm{N}^{\circ} 41 / 05$ & $\begin{array}{l}\text { Massimo Guidolin } \\
\text { Giovanna Nicodano }\end{array}$ \\
\hline$N^{\circ} 42 / 05$ & $\begin{array}{l}\text { Margherita Borella } \\
\text { Flavia Coda Moscarola }\end{array}$ \\
\hline$N^{\circ} 43 / 05$ & $\begin{array}{l}\text { John Beshears } \\
\text { James J. Choi } \\
\text { David Laibson } \\
\text { Brigitte C. Madrian }\end{array}$ \\
\hline
\end{tabular}

Annuity Risk: Volatility and Inflation Exposure in Payments from Immediate Life Annuities

Longevity Risk in Living Benefits

Valuation of Guaranteed Annuity Conversion Options

The Behaviour of UK Annuity Prices from 1972 to the Present

Issues in the Regulation of Annuities Markets

Annuities in Germany before and after the Pension Reform of 2001

New Tools in Micromodeling Retirement Decisions: Overview and Applications to the Italian Case

The Realized Equity Premium has been Higher than Expected: Further Evidence

A Switch Criterion for Defined Contribution Pension Schemes

Risk Aversion and the Utility of Annuities

Older Workers and Pensioners: the Challenge of Ageing on the Italian Public Pension System and Labour Market

A Comparative Analysis of the Costs of Italian Individual Pension Plans

Le Vieillissement Démographique :

Problématique des Régimes de Pension en Tunisie

What Triggers Early Retirement. Results from Swiss Pension Funds

Pensions Systems and the Intergenerational Distribution of Resources

Actuarial Fairness or Social Justice?

A Gender Perspective on Redistribution in Pension Systems

An Empirical Assessment of the Italian Severance Payment (TFR)

Modelling the Surrender Conditions in Equity-Linked Life Insurance

Investing for the Long-Run in European Real Estate. Does Predictability Matter?

Small Caps in International Equity Portfolios: The Effects of Variance Risk.

Distributive Properties of Pensions Systems: a Simulation of the Italian Transition from Defined Benefit to Defined Contribution The Importance of Default Options for Retirement Saving Outcomes: Evidence from the United States 


\begin{tabular}{|c|c|}
\hline$N^{\circ} 44 / 05$ & Henrik Cronqvist \\
\hline$N^{\circ} 45 / 05$ & Claudio Campanale \\
\hline$N^{\circ} 46 / 05$ & $\begin{array}{l}\text { Annamaria Lusardi } \\
\text { Olivia S. Mitchell }\end{array}$ \\
\hline$N^{\circ} 47 / 06$ & $\begin{array}{l}\text { Michele Belloni } \\
\text { Carlo Maccheroni }\end{array}$ \\
\hline$N^{\circ} 48 / 06$ & $\begin{array}{l}\text { Onorato Castellino } \\
\text { Elsa Fornero }\end{array}$ \\
\hline$N^{\circ} 49 / 06$ & Mariacristina Rossi \\
\hline$N^{\circ} 50 / 06$ & $\begin{array}{l}\text { Andrea Buffa } \\
\text { Chiara Monticone }\end{array}$ \\
\hline$N^{\circ} 51 / 06$ & Giovanni Mastrobuoni \\
\hline$N^{\circ} 52 / 06$ & $\begin{array}{l}\text { Luigi Guiso } \\
\text { Tullio Jappelli }\end{array}$ \\
\hline$N^{\circ} 53 / 06$ & Giovanni Mastrobuoni \\
\hline$N^{\circ} 54 / 06$ & $\begin{array}{l}\text { Annamaria Lusardi } \\
\text { Olivia S. Mitchell }\end{array}$ \\
\hline$N^{\circ} 55 / 06$ & Antonio Abatemarco \\
\hline$N^{\circ} 56 / 07$ & $\begin{array}{l}\text { John A. Turner } \\
\text { Satyendra Verma }\end{array}$ \\
\hline $\mathrm{N}^{\circ} 57 / 07$ & $\begin{array}{l}\text { Giovanni Mastrobuoni } \\
\text { Matthew Weinberg }\end{array}$ \\
\hline$N^{\circ} 58 / 07$ & $\begin{array}{l}\text { Elisa Luciano } \\
\text { Jaap Spreeuw } \\
\text { Elena Vigna }\end{array}$ \\
\hline$N^{\circ} 59 / 07$ & $\begin{array}{l}\text { Riccardo Calcagno } \\
\text { Roman Kraeussl } \\
\text { Chiara Monticone }\end{array}$ \\
\hline $\mathrm{N}^{\circ} 60 / 07$ & $\begin{array}{l}\text { Riccardo Cesari } \\
\text { Giuseppe Grande } \\
\text { Fabio Panetta }\end{array}$ \\
\hline $\mathrm{N}^{\circ} 61 / 07$ & Irina Kovrova \\
\hline$N^{\circ} 62 / 07$ & $\begin{array}{l}\text { Margherita Borella } \\
\text { Elsa Fornero } \\
\text { Mariacristina Rossi }\end{array}$ \\
\hline$N^{\circ} 63 / 07$ & Claudio Campanale \\
\hline$N^{\circ} 64 / 07$ & $\begin{array}{l}\text { Carlo Casarosa } \\
\text { Luca Spataro }\end{array}$ \\
\hline$N^{\circ} 65 / 07$ & Annamaria Lusardi \\
\hline
\end{tabular}

Advertising and Portfolio Choice

Increasing Returns to Savings and Wealth Inequality

Financial Literacy and Planning: Implications for Retirement Wellbeing

Actuarial Neutrality when Longevity Increases: An Application to the Italian Pension System

Public Policy and the Transition to Private Pension Provision in the United States and Europe

Examining the Interaction between Saving and Contributions to Personal Pension Plans. Evidence from the BHPS

Do European Pension Reforms Improve the Adequacy of Saving?

The Social Security Earnings Test Removal. Money Saved or Money Spent by the Trust Fund?

Information Acquisition and Portfolio Performance

Labor Supply Effects of the Recent Social Security Benefit Cuts: Empirical Estimates Using Cohort Discontinuities

Baby Boomer Retirement Security: The Roles of Planning, Financial Literacy, and Housing Wealth

On the Measurement of Intra-Generational Lifetime Redistribution in Pension Systems

Why Some Workers Don’t Take 401(k) Plan Offers: Inertia versus Economics

Heterogeneity in Intra-Monthly Consumption. Patterns, SelfControl, and Savings at Retirement

Modelling Stochastic Mortality for Dependent Lives

An Analysis of the Effects of the Severance Pay Reform on Credit to Italian SMEs

La Previdenza Complementare in Italia:

Caratteristiche, Sviluppo e Opportunità per i Lavoratori

Effects of the Introduction of a Funded Pillar on the Russian Household Savings: Evidence from the 2002 Pension Reform

Does Consumption Respond to Predicted Increases in Cash-onhand Availability? Evidence from the Italian "Severance Pay"

Life-Cycle Portfolio Choice: The Role of Heterogeneous UnderDiversification

Rate of Growth of Population, Saving and Wealth in the Basic Life-cycle Model when the Household is the Decision Unit

Household Saving Behavior: The Role of Literacy, Information and Financial Education Programs

(Updated version June 08: “Financial Literacy: An Essential Tool for Informed Consumer Choice?”) 


\begin{tabular}{|c|c|}
\hline$N^{\circ} 66 / 07$ & $\begin{array}{l}\text { Maarten van Rooij } \\
\text { Annamaria Lusardi } \\
\text { Rob Alessie }\end{array}$ \\
\hline $\mathrm{N}^{\circ} 67 / 07$ & $\begin{array}{l}\text { Carolina Fugazza } \\
\text { Maela Giofré } \\
\text { Giovanna Nicodano }\end{array}$ \\
\hline$N^{\circ} 68 / 07$ & $\begin{array}{l}\text { Massimo Guidolin } \\
\text { Giovanna Nicodano }\end{array}$ \\
\hline $\mathrm{N}^{\circ} 69 / 07$ & $\begin{array}{l}\text { Carolina Fugazza } \\
\text { Massimo Guidolin } \\
\text { Giovanna Nicodano }\end{array}$ \\
\hline $\mathrm{N}^{\circ} 70 / 07$ & $\begin{array}{l}\text { Radha Iyengar } \\
\text { Giovanni Mastrobuoni }\end{array}$ \\
\hline$N^{\circ} 71 / 07$ & Flavia Coda Moscarola \\
\hline$N^{\circ} 72 / 08$ & $\begin{array}{l}\text { Annamaria Lusardi } \\
\text { Olivia Mitchell }\end{array}$ \\
\hline$N^{\circ} 73 / 08$ & $\begin{array}{l}\text { Michele Belloni } \\
\text { Rob Alessie }\end{array}$ \\
\hline$N^{\circ} 74 / 08$ & Maela Giofré \\
\hline$N^{\circ} 75 / 08$ & $\begin{array}{l}\text { Harold Alderman } \\
\text { Johannes Hoogeveen } \\
\text { Mariacristina Rossi }\end{array}$ \\
\hline$N^{\circ} 76 / 08$ & $\begin{array}{l}\text { Riccardo Calcagno } \\
\text { Elsa Fornero } \\
\text { Mariacristina Rossi }\end{array}$ \\
\hline $\mathrm{N}^{\circ} 77 / 08$ & $\begin{array}{l}\text { Giovanni Guazzarotti } \\
\text { Pietro Tommasino }\end{array}$ \\
\hline$N^{\circ} 78 / 08$ & $\begin{array}{l}\text { Margherita Borella } \\
\text { Giovanna Segre }\end{array}$ \\
\hline $\mathrm{N}^{\circ} 79 / 08$ & Annamaria Lusardi \\
\hline $\mathrm{N}^{\circ} 80 / 08$ & Claudio Campanale \\
\hline$N^{\circ} 81 / 09$ & $\begin{array}{l}\text { Fabio Bagliano } \\
\text { Claudio Morana }\end{array}$ \\
\hline$N^{\circ} 82 / 09$ & $\begin{array}{l}\text { Carolina Fugazza } \\
\text { Massimo Guidolin } \\
\text { Giovanna Nicodano }\end{array}$ \\
\hline$N^{\circ} 83 / 09$ & $\begin{array}{l}\text { Annamaria Lusardi } \\
\text { Peter Tufano }\end{array}$ \\
\hline$N^{\circ} 84 / 09$ & Luca Spataro \\
\hline$N^{\circ} 85 / 09$ & $\begin{array}{l}\text { Cathal O’Donoghue } \\
\text { John Lennon } \\
\text { Stephen Hynes }\end{array}$ \\
\hline
\end{tabular}

Financial Literacy and Stock Market Participation

International Diversification and Labor Income Risk

Small Caps in International Diversified Portfolios

Investing in Mixed Asset Portfolios: the Ex-Post Performance

The Political Economy of the Disability Insurance. Theory and Evidence of Gubernatorial Learning from Social Security Administration Monitoring

Women participation and caring decisions: do different institutional frameworks matter? A comparison between Italy and The Netherlands

Planning and Financial Literacy: How Do Women Fare?

The Importance of Financial Incentives on Retirement Choices: New Evidence for Italy

Information Asymmetries and Foreign Equity Portfolios: Households versus Financial Investors

Preschool Nutrition and Subsequent Schooling Attainment: Longitudinal Evidence from Tanzania

The Effect of House Prices on Household Saving: The Case of Italy

The Annuity Market in an Evolving Pension System: Lessons from Italy

Le pensioni dei lavoratori parasubordinati: prospettive dopo un decennio di gestione separata

Increasing the Effectiveness of Financial Education in the Workplace

Learning, Ambiguity and Life-Cycle Portfolio Allocation

Permanent and Transitory Dynamics in House Prices and Consumption: Cross-Country Evidence

Time and Risk Diversification in Real Estate Investments: Assessing the Ex Post Economic Value

Debt Literacy, Financial Experiences, and Overindebtedness

Il sistema previdenziale italiano dallo shock petrolifero del 1973 al Trattato di Maastricht del 1993

The Life-Cycle Income Analysis Model (LIAM): A Study of a Flexible Dynamic Microsimulation Modelling Computing Framework 
No 86/09 Margherita Borella Flavia Coda Moscarola
Microsimulation of Pension Reforms: Behavioural versus Nonbehavioural Approach 